Journal of Sport Coaching and Physical Education 3 (1) (2018)

\title{
INDEKS KEPUASAN PELAKSANAAN KULIAH KERJA LAPANGAN PADA JURUSAN PENDIDIKAN KEPELATIHAN OLAHRAGA TAHUN 2018
}

\author{
Tri Tunggal Setiawan, Soedjatmiko
}

Jurusan Pendidikan dan Kepelatihan Olahraga, Fakultas Ilmu Keolahragaan, Universitas Negeri Semarang, Indonesia

\begin{abstract}
Info Artikel
Abstrak

Sejarah Artikel:

Diterima Juli 2018

Disetujui Agustus 2018

Dipublikasikan Agustus 2018

Keywords:

work visit, comparative study

Penelitian ini dilakukan untuk membuat index kepuasan pelaksanaan Kuliah Kerja Lapangan (KKL) sebagai bahan evaluasi pelaksanaan KKL.. Pengambilan data dilakukan pada mahasiswa yang sudah melaksanakan kegiatan KKL. Penelitian ini melibatkan 171 mahasiswa jurusan PKLO. Penelitian dilakukan dalam 5 tahap, yaitu: tahap pertama persiapan dengan membuat kisikisi angket dan membuat pertanyaan sesuai kisi-kisi yang sudah disusun. Tahap kedua melakukan uji validitas dan reliabilitas terhadap angket yang sudah disusun dan akan digunakan untuk mengumpulkan data. Tahap ketiga pelaksanaan pengumpulan data dengan membagi angket kepada mahasiswa angkatan 2014 dan 2015 yang sudah melaksanakan KKL pada tahun 2016 dan 2017. Tahap keempat dan kelima merupakan tahap analisis hasil dan pembuatan laporan. Angket berisi data yang akan dievaluasi meliputi: lokasi KKL, manfaat kegiatan KKL, Pembimbing, biaya, kendaraan, lokasi wisata, penginapan, konsumsi dan lain-lain. Hasil penelitian akan digunakan oleh manajemen Jurusan PKLO FIK untuk menentukan kebijakan dan langkah terbaik dalam menyelenggarakan kegiatan KKL agar benar-benar bermanfaat bagi mahasiswa dan lembaga.
\end{abstract}

\section{Abstract}

This research was conducted to create a satisfaction index for the implementation of Field Work Courses (KKL) as an evaluation material for the implementation of the MPA which is carried out annually by students of the Sports Coaching Education Department (PKLO) of the Faculty of Sport Sciences (FIK). This research needs to be done because there are always problems that accompany the implementation of the MPA, even though the problems that arise are different every year. Data collection is carried out on students who have carried out MPA activities. This study involved 171 students from PKLO. The research was conducted in 5 stages, namely: the first stage of preparation by making a questionnaire grid and making questions according to the grid that had been compiled. The second stage tests the validity and reliability of the questionnaire that has been compiled and will be used to collect data. The third stage of the data collection was by dividing the questionnaire to students of the class of 2014 and 2015 who had implemented the MPA in 2016 and 2017. The fourth and fifth stages were the results of the analysis and preparation of the report. Questionnaires containing data to be evaluated include: MPA location, benefits of MPA activities, advisors, fees, vehicles, tourist sites, lodging, consumption and others. The results of the study will be used by the management of the PKLO FIK Department to determine the best policies and steps in organizing MPA activities so that they are truly beneficial for students and institutions.

(c) 2018 Universitas Negeri Semarang

\footnotetext{
Alamat korespondensi:

Gedung F1 Lantai 3 FIK UNNES

Kampus Sekaran, Gunungpati, Semarang, 50229

E-mail: jscpe.pklo@unnes.ac.id
}

ISSN 2548-4885 


\section{PENDAHULUAN}

Kuliah Kerja Lapangan (KKL) merupakan bentuk kegiatan yang memberikan pengalaman belajar kepada mahasiswa, bertujuan agar mahasiswa dapat menerapkan dan mengembangkan ilmu pengetahuan dan pengalaman yang didapat di bangku kuliah untuk meningkatkan kualitas. KKL merupakan kegiatan wajib yang diikuti oleh setiap mahasiswa semester 4 Jurusan Pendidikan Kepelatihan Olahraga Fakultas Ilmu Keolahragaan Universitas Negeri Semarang. Kegiatan KKL didampingi oleh dosen pembimbing akademik masing-masing dengan mengunjungi berbagai lokasi yang setiap tahun selalu berganti. Meski kegiatan KKL sudah dilakukan bertahun-tahun, namun selalu saja muncul permasalahan, meski permasalahan yang ada berbeda setiap tahunnya. Permasalah bisa karena lokasi tujuan KKL, manfaat KKL, biaya, kendaraan, lokasi wisata, penginapan, konsumsi, dan lain-lain. Permasalahan yang paling menonjol adalah mahasiswa tanpa membuat laporan kegiatan setelah pulang ke kampus.

Sesuai dengan visi dan misi Universitas Negeri Semarang (UNNES) sebagai lembaga pendidikan yang bertekad mengembangkan diri menjadi rumah ilmu pengembang peradaban unggul. Dengan tekad itu, UNNES menjaga jati dirinya sebagai lembaga ilmu pengetahuan yang bertugas mengembangkan potensi sumber daya manusia Indonesia untuk membangun keunggulan bangsa dan manfaat bagi manusia dan kemanusiaan. Dengan menjadi rumah ilmu berarti UNNES selalu menggunakan ilmu sebagai dasar dalam setiap kegiatan. Kegiatan keilmuan terepresentasi dalam bentuk kegiatan intrakurikuler dan ekstrakurikuler, bidang akademik maupun nonakademik. Secara akademik, kegiatan pengembangan keilmuan dilaksanakan di program studi, laboratorium, dan kegiatan lainnya. Adapun secara nonakademik, ilmu menjadi dasar dalam pengelolaan dan pengambilan kebijakan universitas (http://UNNES.ac.id/tentang Peraturan Rektor no 29 tahun 2016).

Salah satu bentuk kegiatan untuk mewujudkan itu semua dengan $\mathrm{KKL}$ karena kegiatan ini merupakan kegiatan yang memadukan observasi, kunjungan dan wisata. Objek kunjungan KKL dapat berupa tempat, instansi atau lembaga yang berhubungan dengan kewirausahaan, sains, iptek, maupun lembaga pendidikan yang berkaitan dengan disiplin ilmu yang ditekuni mahasiswa.

Berbeda dengan Kuliah Kerja Nyata (KKN), kegiatan KKL lebih banyak melibatkan kegiatan pengamatan atau observasi tanpa wajib melakukan pemberdayaan kepada masyarakat. Sedangkan kegiatan KKN memang mewajibkan mahasiswa untuk langsung memberikan kontribusi kepada masyarakat melalui pengabdian dan pemberdayaan masyarakat. Pengalaman belajar yang diharapkan dari kegiatan KKL adalah dapat memberikan bekal hidup dalam bersosialisasi, menghadapi masalah, dan mengabdi kepada masyarakat setelah lulus dari perguruan tinggi. Kegiatan KKL harus ada esensi kebermanfaatan yang diperoleh mahasiswa, yaitu mahasiswa dapat membandingkan antara teori yang telah diperoleh di bangku perkuliahan dengan aplikasinya di dunia nyata, dapat mengetahui seluk beluk profesi yang berkaitan dengan bidang studi yang sedang dipelajari, sehingga mahasiswa akan lebih siap ketika masuk dunia kerja.

Kegiatan KKL seharusnya diakhiri dengan pembuatan laporan sebagai tolak 
ukur keberhasilan KKL yang berisi deskripsi kegiatan KKL. Sayangnya, karena hasil pelaksaan kegiatan KKL berupa laporan tertulis, maka banyak mahasiswa saling meniru laporan mahasiswa satu dengan yang lainnya. Kebiasaan buruk budaya copy paste laporan menjadikan mahasiswa berpandangan bahwa KKL hanya sebagai ajang berwisata dan berekreasi dengan mengesampingkan tujuan utama KKL. Objek tujuan KKL pun sekarang ini cenderung ke tempat-tempat wisata seperti pantai, museum, dan instansi yang sebenarnya kurang sesuai dengan disiplin ilmu yang tengah ditekuni. Hal ini berlangsung terus-menerus hingga melahirkan mindset mahasiswa bahwa KKL adalah saat untuk berwisata. Tujuan sesungguhnya dari KKL lebih sering dikesampingkan. Selain itu, objek KKL dengan tempat yang jauh tentu membutuhkan dana tidak sedikit. Dosen pembimbing sebenarnya memiliki peranan yang sangat penting dalam KKL. Dosen hendaknya mengarahkan, membimbing, dan mengawal berjalannya KKL. Dosen juga merupakan evaluator kegiatan KKL untuk mengevaluasi keberhasilan KKL untuk segera melakukan perbaikan kegiatan KKL berikutnya sehingga tujuan pelaksanaan KKL dapat benar-benar tercapai. Namun kenyataannya, beberapa dosen yang ikut sebagai pembimbing hanya memanfaatkan wisata gratis dari kegiatan ini untuk melepas penat rutinitas mengajar sehari-hari (Marlinda, 2012). Sesuai pedoman akademik UNNES kegiatan KKL harus ditindaklanjuti dengan penyusunan laporan kegiatan, evaluasi kegiatan, atau seminar hasil KKL.

Kuliah Kerja Lapangan (KKL) adalah kegiatan ilmiah yang berupa kajian materi perkuliahan dengan menggunakan pendekatan keilmuan terhadap objek di luar kelas yang terkait dengan Jurusan/Program Studi/Bagian tertentu. Kegiatan tersebut dilakukan oleh mahasiswa di bawah bimbingan dosen pembimbing. KKL merupakan salah satu kegiatan penunjang pengembangan materi kuliah atau keilmuan program studi. KKL dapat dilaksanakan sebagai kegiatan kokurikuler. KKL sebagai kegiatan kurikuler diatur oleh program studi masing-masing sesuai dengan kekhasan program studi (Peraturan Rektor no 29 tahun 2016).

Tujuan

KKL bertujuan agar mahasiswa memperoleh pengetahuan dan keterampilan yang berkenaan dengan penerapan konsep, teori, dan pengetahuan yang diperoleh di kelas. Melalui KKL mahasiswa diharapkan tidak hanya menguasai pengetahuan secara teoretis saja tetapi dapat pula mengenal dan mengidentifikasi praktik penerapannya dalam bentuk aktivitas yang sesungguhnya.

Frekuensi dan Obyek

KKL dilakukan sekurangkurangnya sekali selama masa studi. Objek dan topik KKL ditentukan oleh Fakultas/Jurusan/Program

Studi/Bagian/Pascasarjana bersama dosen pembimbing KKL dan mahasiswa. Objek dan topik pelaksanaan $\mathrm{KKL}$ disesuaikan dengan subtansi kajian mata kuliah program studi.

\section{Bentuk Kegiatan}

KKL dapat dibagi menjadi tiga tahap kegiatan.

Tahap Persiapan. Bentuk kegiatan pada tahap persiapan adalah perencanaan kegiatan yang meliputi pembentukan kepanitiaan, penentuan tujuan dan topik KKL, penentuan objek dan lokasi KKL, penyusunan desain kegiatan dan pembiayaan serta pembekalan oleh dosen pembimbing KKL. 
Tahap Pelaksanaan. KKL dilaksanakan sesuai dengan perencanaan dan desain kegiatan yang telah dirumuskan. Kegiatan yang dilakukan selama pelaksanaan KKL berorientasi pada pencapaian tujuan kegiatan. Selama pelaksanaan kegiatan mahasiswa dibimbing oleh dosen dan pembimbing lapangan/pemandu.

Tahap Tindak Lanjut. Pelaksanaan KKL ditindaklanjuti dengan penyusunan laporan kegiatan, evaluasi kegiatan, atau seminar hasil KKL.

\section{Peserta Kegiatan}

Peserta KKL adalah mahasiswa program kependidikan dan nonkependidikan program D3 dan S1 serta program S2 dan S3.

\section{Persyaratan KKL}

Persyaratan mengikuti KKL adalah mahasiswa yang sekurang-kurangnya telah menempuh 4 semester bagi mahasiswa S1, dan sekurang-kurangnya telah menempuh dua semester bagi mahasiswa program D3, S2 dan S3.

\section{Pembiayaan}

Kegiatan KKL dibiayai dari swadaya mahasiswa, ditambah dengan bantuan dari fakultas.

\section{Mahasiswa PKLO}

Jurusan Pendidikan Kepelatihan Olahraga merupakan salah satu jurusan pada Fakultas Ilmu Keolahragaan Universitas Negeri Semarang. Jurusan lain di fakultas ini adalah Pendidikan Jasmani, Kesehatan, dan Rekreasi (PJKR), Ilmu Keolahragaan (IKOR), dan Ilmu Kesehatan Masyarakat (IKM). Jumlah mahasiswa PKLO angkatan tahun 2014 adalah 168 mahasiswa terdiri dari laki-laki 132 mahasiswa dan perempuan 36 mahasiswa. Angkatan tahun 2015 berjumlah 174 terdiri dari 124 mahasiswa laki-laki dan 50 mahasiswa perempuan
(http://data.UNNES.ac.id/index.php/m hs/aktif).

Objek Kuliah Kerja Lapangan di Jurusan PKLO

Kuliah Kerja Lapangan (KKL) merupakan kegiatan instruksional yang dilaksanakan oleh lembaga pendidikan seperti UNNES. Oleh karena itu KKL merupakan metode mengajar yang mengembangkan ketiga domain (afektif, kognitif dan psikomotorik). Mulyantari (2005) menemukan yang lain, yaitu KKL merupakan kesempatan yang tepat untuk mengembangkan potensi dalam hal berpikir, berketrampilan, dan berkepribadian, karena terjadi interaksi antara mahasiswa dengan objek belajar sehingga dapat dijadikan sebagai salah satu pembelajaran kontekstual. Dipihak lain, Dewi Listiana (2009) tidak menemukan adanya korelasi antara kegiatan KKL dengan nilai yang didapat. Oleh karena itu objek kunjungan KKL menjadi penting agar tujuan kebermanfaatan dan kebermaknaan pelaksanaan KKL benar-benar terwujud sebanding dengan biaya yang harus dikeluarkan oleh mahasiswa. Berikut tempat-tempat yang bisa dikunjungi sebagai objek kunjungan KKL di jurusan PKLO.

\section{Perguruan Tinggi}

Objek kunjungan KKL yang sering dilakukan oleh mahasiswa jurusan PKLO adalah kunjungan ke perguruan tinggi dengan mengadakan try out atau latih tanding pada cabang olahraga sepak bola, bolavoli, bolabasket, futsal, tenis, dan bulu tangkis. Perguruan tinggi paling favorit yang menjadi tempat kunjungan adalah Undhiksa Singaraja Bali dan Unesa Surabaya. Hal ini disebabkan karena ratarata mahasiswa menjadikan Pulau Bali sebagai tempat paling favorit sebagai destinasi pariwisata. Sebenarnya objek kunjungan kependidikan bisa dilakukan ke 
objek Pusat Pengembangan dan Pemberdayaan Pendidik dan Tenaga Kependidikan (PPPTK) seperti yang dilakukan mahasiswa jurusan Teknik Elektro UNNES tahun 2015 (http://www.academia.edu.KKLTeknikE lektro2015UNNES).

\section{Kewirausahaan}

Selama pelaksanaan KKL, belum pernah jurusan PKLO mengunjungi home industri pembuatan produk yang terkait dengan olahraga, seperti pembuatan sepatu olahraga, pembuatan shuttlecock, pembuatan bola, sablon kaos seragam olahraga, dan home industri lain yang berkaitan dengan produk dan asesoris olahraga. Sebenarnya kunjungan ke home industri seperti ini dapat bermanfaat untuk mengasah dan menginspirasi jiwa kewirausahaan mahasiswa setelah lulus. Contoh home industri yang bisa dikunjungi antara lain Adis Dimension Footwear, Pt / Mitra Corp, Dwi Naga Sakti Abadi, dan Horn Ming Indonesia yang khusus membuat peralatan sepatu olahraga

(http://alamatjabodetabek.blogspot.co.id/ 2016 /12/daftar-industri-sepatu-sandaldi.html).

\section{Manajemen Olahraga}

Olahraga sudah merupakan industri yang bisa dikembangkan untuk menghasilkan rupiah. Apabila industri ini dikelola dengan baik maka akan menjadi profesi yang menjanjikan. Event organitation olahraga sering dikelola oleh orang yang tidak punya latar belakang olahraga. Untuk itu perlu juga mahasiswa PKLO dibekali dengan terjun langsung untuk menggali segala seluk beluk dan informasi tentang EO ini. Selain EO objek KKL lain yang cocok bagi mahasiswa PKLO adalah KONI, Kemenpora, dan Dinpora yang secara kelembagaan mengatur dan menjalankan kebijakan dibidang olaharaga.

\begin{abstract}
Klub Olahraga
Mengelola klub olahraga secara profesional juga bisa menjadi profesi pokok bagi lulusan PKLO karena bidang ini merupakan garapan paling utama bagi jurusan PKLO. Namun demikian sampai dengan tahun 2017, belum pernah jurusan PKLO mengunjungi sebuah klub besar seperti Jarum Kudus, Petro Kimia Gresik, PLN maupun mengunjungi pusat-pusat latihan (Pelatnas) yang disiapkan untuk even internasional seperti di Cipayung.
\end{abstract}

\section{METODE}

Penelitian ini termasuk penelitian survei lapangan dengan desain dan metode penelitian secara lengkap dan sistematis disebutkan sebagai berikut:

\section{Variabel}

Variabel dalam penelitian ini meliputi, variabel bebas: index kepuasan pelaksanaan KKL. Variabel bergantung: lokasi KKL, manfaat kegiatan KKL, Pembimbing, biaya, kendaraan, lokasi wisata, penginapan, konsumsi. Variabel luar yag diperhatikan: semester dan rombel. Variabel luar terkendali: jenis kelamin dan umur.

\section{Rancangan Penelitian}

Penelitian ini tergolong penelitian survei lapangan dengan bentuk rancangan sebagai berikut:

mahasiswa $\longrightarrow \mathrm{X}_{1} \longrightarrow \mathrm{X}_{2}$

$\mathrm{X}_{1}$ : pelaksanaan survei (pengisian angket), $\mathrm{X}_{2}$ : pencatatan hasil survey

\section{Populasi dan Sampel}

Populasi dalam penelitian ini adalah mahasiswa PKLO semester 4 dan 6 yang sudah melaksanakan KKL berjumlah 342 mahasiswa terdiri dari angkatan 2015 sejumlah 174 (laki-laki 124 mahasiswa dan perempuan 50 mahasiswa) dan angkatan 2014 adalah 168 (laki-laki 
132 mahasiswa dan perempuan 36 mahasiswa).

\section{Alat Yang Dipakai}

Alat yang dipakai untuk mendapatkan data penelitian meliputi: KKL.

Kuesioner tentang pelaksanaan

Blangko-blangko pencatat hasil.

\section{Jalan Penelitian}

Pengambilan data dilakukan selama 2 hari dengan rincian sebagai berikut:

Tempat dan waktu: Tempat pengambilan data penelitian dilaksanakan pada bulan September 2018.

Variabel yang diteliti meliputi: lokasi KKL, manfaat kegiatan KKL, Pembimbing, biaya, kendaraan, lokasi wisata, penginapan, konsumsi.

Persetujuan sebagai sampel: Subjek yang menolak dijadikan sampel akan dicoret sebagai subjek dan dicarikan pengganti untuk melengkapi jumlah sampel.

Pengambilan data dan pencatatan hasil: Pengambilan data dan pencatatan hasil dibantu oleh 4 orang pembantu penelitian.

\section{Teknik Analisis Hasil}

Analisis statistik dilakukan dengan metode analisis statistik deskriptif.

\section{PEMBAHASAN}

\section{Manfaat kegiatan KKL}

Berdasarkan data penelitian, 40\% sampel menyatakan kegiatan KKL tahun 2018 kurang bermanfaat. Hal itu dikuatkan dengan pernyataan tertulis dalam kolom kesan, pesan, dan saran bahwa kegiatan KKL hanya berwisata dan belanja. Minim sekali adanya kegiatan yang berkaitan secara langsung dengan bidang ilmu mahasiswa sehingga dirasa tidak memberikan manfaat bagi mahasiswa saat ini dan sebagai bekal lulus nanti. Hasil penelitian ini harus dijadikan bahan evaluasi bagi Jurusan untuk membenahi kegiatan KKL berikutnya. Hal ini berkaitan erat dengan pemilihan lokasi kunjungan dan persiapan matang jauh hari sebelum pemberangkatan.

\section{Peran dosen pembimbing}

Dosen pembimbing akademik dinyatakan kurang berperan selama KKL oleh $20 \%$ sampel. Hal tersebut dikarenakan tidak ada agenda khusus antara mahasiswa bimbingan dengan dosen pembimbing akademik untuk berdialog mengenai substansi dari kegiatan KKL. Sebanyak 60\% sampel menyatakan perlu adanya agenda tersebut, dan $22 \%$ sampel menyatakan sangat perlu. Selain itu dari panitia tidak menyampaikan secara jelas tugas fungsi dosen pembimbing pada kegiatan tersebut apa saja. Untuk kegiatan KKL berikutnya diharapkan ada agenda khusus dialog antara dosen pembimbing akademik dengan mahasiswa bimbingan. Serta adanya kejelasan tugas fungsi dosen pembimbing pada kegiatan KKL.

\section{Biaya KKL}

Biaya KKL dinilai tidak sebanding oleh 34\% sampel, dan dinyatakan sangat mahal oleh $26 \%$ sampel. Hal ini menjadi catatan bagi panitia bahwa penilaian kesebandingan tidak hanya dinilai dari nominal biaya tetapi juga dengan manfaat yang didapatkan. Sedangkan penilaian mahal tidaknya biaya dilihat dari kemampuan mahasiswa. Walaupun biaya KKL Jurusan Pendidikan Kepelatihan Olahraga tahun 2018 terbilang relatif lebih rendah jika dibandingkan dengan kegiatan serupa oleh penyelenggara lain.

\section{Kendaraan}

Tepat sebanyak $12 \%$ sampel menyatakan kendaraan kurang nyaman dan kurang memuaskan. Artinya angka ketidakpuasan cukup rendah. Strategi pemilihan armada pada KKL tahun 2018 
bisa dijadikan rujukan untuk kegiatan KKL di tahun berikutnya.

\section{Lokasi KKL}

Lokasi KKL merupakan salah satu hal penting yang turut menentukan ketercapaian tujuan kegiatan KKL. Berdasarkan data penelitian $87 \%$ sampel mengatakan tidak puas dengan lokasi KKL yang berkaitan dengan bidang keilmuan mahasiswa. Angka tersebut sangatlah besar dan bisa menjadi gambaran bahwa tujuan inti dari kegiatan KKL dinyatakan tidak tercapai. Berdasarkan perencanaan yang disampaikan kepada mahasiswa, ada 3 tempat utama yang akan dikunjungi yaitu klub sepakbola Bali United, Joger, dan Bali Tree Top.

Kunjungan ke Bali United diharapkan mahasiswa bisa belajar ilmu kepelatihan tingkat lanjut untuk cabang olahraga sepakbola, manajemen organisasi, dan latih tanding dengan klub kasta tertinggi sepakbola Indonesia. Akan tetapi kunjungan tersebut gagal. Berikutnya Joger, mahasiswa direncanakan masuk ke dapur produksi Joger dengan pemilik Joger sendiri memberikan workshop sehingga mahasiswa bisa belajar kewirausahaan sebagai bekal lulus nanti. Rencana tersebut tidak berjalan sesuai rencana, mahasiswa dating ke Joger hanya berbelanja tanpa ada penerimaan dari pemilik dan tidak ada workshop kewirausahaan. Kunjungan utama terakhir adalah Bali Tree Top, dimana mahasiswa diharapkan bisa belajar pengelolaan wisata outbond yang berbasis potensi alam. Melatih mental melalui aktivitas fisik yang menyenangkan dan menantang. Tetapi pada pelaksanaannya mahasiswa hanya sebagai peserta outbond dengan minim sekali penjelasan terkait manajemen pengelolaan dan berbagai informasi penting lainnya. $\begin{array}{lrrr}\text { Lokasi wisata } & \text { yang dikunjungi } \\ \text { sudah memenuhi } & \text { harapan dari } \\ \text { mahasiswa. Hanya } & \text { sebanyak } & 12 \%\end{array}$ mahasiswa yang menyatakan kurang puas dengan lokasi wisata. Selebihnya menyatakan puas dan sangat puas. Catatan dari sampel adalah untuk lebih memperhatikan jumlah lokasi wisata dengan waktu kunjungan.

\section{Penginapan}

Aspek yang perlu diperhatikan dari penginapan adalah daya tampung kamar dengan jumlah penghuni kamar. Sebanyak 54\% sampel menyatakan tidak nyaman dengan pembagian 1 kamar diisi 4 orang. Idealnya 1 kamar diisi 1 orang menurut $66 \%$ sampel, diisi 2 orang menurut $32 \%$ sampel, dan diisi 4 orang oleh $2 \%$ sampel. Namun demikian secara keseluruhan penginapan dianggap kurang memuaskan hanya oleh $18 \%$ sampel. Yang artinya penginapan tersebut sudah cukup nyaman sebagai tempat singgah KKL dengan catatan penyesuaian jumlah penghuni dengan kapasitas kamar.

\section{Konsumsi}

Konsumsi sepanjang pelaksanaan KKL disediakan oleh beberapa rumah makan. Masing-masing rumah makan memiliki kualitas pelayanan, menu, dan ukuran porsi masing-masing. Hanya $12 \%$ sampel yang menyatakan kurang puas dengan kualitas konsumsi selama pelaksanaan KKL. Data itu menunjukkan bahwa penyediaan konsumsi sudah cukup baik.

\section{Lain-lain}

Pelaksanaan KKL yang dinganggap kurang terencana oleh $68 \%$ sampel dan dianggap tidak terencana oleh $4 \%$ sampel merupakan fakta yang kurang baik. Peneliti melakukan komunikasi dengan panitia terkait persepsi sampel yang menyatakann pelaksanaan KKL kurang terencana. Panitia menyampaikan bahwa perencanaan sudah dilakukan 4 bulan 
sebelum pelaksanaan KKL. Panitia melakukan koordinasi dengan seluruh peserta sebanyak 4 kali pertemuan, dan koordinasi dengan perwakilan mahasiswa lebih dari 8 kali. Panitia mengakui bahwa lokasi kunjungan utama KKL yaitu ke Bali United, workshop kewirausahaan di Joger, dan manajemen pengelolaan outbond di Bali Tree Top justru yang tidak berjalan sesuai rencana. Hal itulah yang menyebabkan sampel memiliki persepsi KKL kurang terencana.

Namun demikian secara keseluruhan penyelenggaraan kegiatan KKL Jurusan Pendidikan Kepelatihan Olahraga tahun 2018 dinilai kurang memuaskan hanya oleh $26 \%$ sampel. Selebihnya dinilai memuaskan oleh $54 \%$ sampel, sangat memuaskan oleh $18 \%$ sampel, dan $2 \%$ sampel memilih untuk tidak memberikan penilaian. Secara keseluruhan penyelenggaraan KKL sudah berjalan dengan cukup baik terbukti dengan indeks kepuasaan mahasiswa yang cukup tinggi mencapai $72 \%$ sampel.

\section{SIMPULAN}

Berdasarkan analisis data penelitian, maka dapat ditarik beberapa kesimpulan sebagai berikut:

Kegiatan KKL dinilai kurang memberikan manfaat bagi mahasiswa dalam memberikan bekal ilmu pendukung perkuliahan maupun bekal setelah lulus nanti.

Peran dosen pembimbing cukup baik namun perlu ditambahkan agenda khusus antara dosen pembimbing akademik dengan mahasiswa bimbingannya untuk berdiskusi khususnya mengenai pelaksanaan KKL maupun halhal lain yang menunjang kegiatan akademik.

Biaya KKL cukup wajar, tetapi masih dianggap sangat mahal oleh seperempat sampel yang mungkin memiliki latar belakang ekonomi menengah ke bawah.

\section{Kendaraan}

Kendaraan dinilai memuaskan oleh sebagian sampel, dan strategi pemilihan armada pada KKL tahun 2018 bisa diterapkan untuk KKL tahun berikutnya.

\section{Lokasi KKL}

Lokasi kunjungan utama KKL tidak memuaskan mahasiwa karena tidak sesuai dengan perencanaan yang dipaparkan kepada mahasiswa, dan mahasiswa tidak mendapatkan manfaat keilmuan. Akan tetapi kunjungan ke lokasi wisata sudah memuaskan mahasiswa.

\section{Penginapan}

Penginapan dinilai nyaman dan memuaskan. Yang menjadi catatan adalah pembagian 4 orang dalam satu kamar yang dinilai melebihi kapasitas kamar sehingga dirasa kurang nyaman.

\section{Konsumsi}

Konsumsi KKL dianggap memuaskan sehingga perlu dipertahankan untuk penyelenggaraan KKL tahun berikutnya.

\section{Lain-lain}

Secara keseluruhan pelaksanaan KKL dianggap memuaskan oleh $72 \%$ sampel. Indeks kepuasan yang cukup tinggi pada pelaksanaan KKL Jurusan Pendidikan Kepelatihan Olahraga Tahun 2018.

\section{Saran}

Penelitian ini diharapkan dapat memberikan manfaat bagi beberapa pihak. Namun demikian penelitian ini jauh dari sempurna. Berikut saran yang dapat peneliti sampaikan:

Manajemen Jurusan Pendidikan Kepelatihan Olahraga perlu melakukan peran controlling terkait perencanaan, penyelenggaraan, dan pasca penyelenggaraan seperti pelaporan 
kegiatan KKL baik dari panitia maupun mahasiswa. Sehingga kegiatan KKL berjalan sesuai visi dan misi jurusan dan mahasiswa mendapatkan manfaat yang besar dari kegiatan KKL tersebut.

Panitia penyelenggara KKL perlu mencermati hasil analisis data dan kesimpulan penelitian sebagai tolok ukur dalam melakukan evaluasi kegiatan sehingga dapat dilakukan perbaikan dan peningkatan penyelenggaraan KKL tahun berikutnya agar tercapai indeks kepuasan yang lebih tinggi.

Penitia penyelenggara perlu berkoordinasi dengan pihak-pihak terkait secara matang sehingga tidak menimbulkan ketidakpastian atau bahkan kegagalan dari perencanaan awal yang dapat menyebabkan ketidakpuasan peserta.

Panitia penyelenggara perlu memiliki rencana kedua sehingga apabila rencana pertama gagal, tujuan dan manfaat kegiatan KKL masih dapat tercapai.

Panitia untuk lebih melibatkan mahasiswa dalam proses perencanaan dan pelaksanaan KKL sehingga komunikasi dua arah berjalan dengan baik untuk membangun kepercayaan dan rasa memahami keadaan masing-masing pihak.

Bagi peneliti lain yang akan melakukan penelitian serupa diharapkan untuk menambah jumlah sampel dan menyusun instrument tes yang lebih baik sehingga data penelitian yang diperoleh akan lebih valid dan dapat dipertanggungjawabkan.

\section{DAFTAR PUSTAKA}

Dewi Listiana. 2009. Hubungan Aktivitas Mahasiswa dalam Kegiatan Kuliah Kerja Lapangan (KKL) II dengan Nilai yang Diperoleh Mahasiswa
Prodi Geografi FIS UNNES Angkatan 2006. Skripsi. Jurusan Geografi Fakultas Ilmu Sosial Universitas Negeri Semarang.

Dicky Arinta, Sugeng Utaya, I Komang Astina. 2016. Implementasi Pembelajaran Kuliah Kerja Lapangan Dalam Meningkatkan Minat Belajar Mahasiswa Program Studi Pendidikan Geografi Universitas Negeri Malang. Jurnal Pendidikan: Teori, Penelitian, dan Pengembangan Volume: 1 nomor: 8: 1665-1670.

UNNES. 2016. Peraturan Rektor no 29 tahun 2016 tentang Pedoman Akademik UNNES Tahun 2016 http://dokumen.tips/document/tuj uan-dan-manfaat-kkl-fixed.html. (diakses 3 Maret 2017)

https://joglosemar.co/2013/02/kklpenting-nggak-sih.html. (diakses 3 Maret 2017)

Marlinda.kkl-bukan-sekedar-jalan-jalan https://smilingshine.wordpress.co m/2012/ 11/03/ (diakses 3 Maret 2017)

Mulyantari. 2005 "Kuliah Kerja Lapangan( KKL ) I Geografi Sebagai Salah Satu Metode Pembelajaran Kontekstual dan Pengaruhnya Terhadap Prestasi Belajar Mahasiswa Pendidikan Geografi". Jurusan Geografi . FIS. UNNES 62 halaman. https://www.google.com/ jurnal+kk1+geografi+UNNES. (diakses 3 Maret 2017)

UNNES. 2016. Mahasiswa aktif. http://data.UNNES.ac.id/index.p $\mathrm{hp} / \mathrm{mhs} /$ aktif. (diakses 3 Maret 2017)

http://alamatjabodetabek.blogspot.co.id/ 2016 /12/daftar-industri-sepatusandal-di.html. (diakses 3 Maret 2017) 
Tri Tunggal Setiawan / Journal of Sport Coaching and Physical Education 3 (1) (2018)

http://www.academia.edu.KKLTeknikEl

ektro2015UNNES. (diakses 3

Maret 2017)

UNNES. 2016. Visi dan Misi UNNES

http://UNNES.ac.id/ . (diakses 3

Maret 2017) 